\title{
Riskiperusteiset maksut eläintautivahinkojen rahoituksessa
}

\author{
Jaakko Heikkilä ja Jarkko K. Niemi
}

MTT Taloustutkimus, Luutnantintie 13,00410 Helsinki, etunimi.sukunimi@mtt.fi

\section{Tiivistelmä}

Euroopan Unionissa on esitetty tuottajien vastuun lisäämistä vakavimpien eläintautien vahinkojen rahoituksessa. Toteutuskeinoina on mainittu muun muassa eläintautirahastomaksu tai -vakuutus. Tähän asti yhteiskunta on kantanut vastuun yhteiskunnallisesti merkittävimpien eläintautien välittömistä menetyksistä. Tilanne on hyödyttänyt riskinottoon halukkaita toimijoita. Esimerkiksi vuosina 1995-2004 EU:n eläintautirahasto maksoi vahingonkorvauksia yhteensä miljardi euroa, josta Iso-Britannian ja Alankomaiden osuus oli $85 \%$ (mm. suu- ja sorkkatauti, klassinen sikarutto ja korkeapatogeeninen lintuinfluenssa). Kymmenkunta vähiten korvauksia saanutta maata sai yhteensä $2 \%$ korvauksista. Tautien ennaltaehkäisyyn ei varoja juuri ole ollut käytettävissä.

Pienellä todennäköisyydellä esiintyviin ja suurta vahinkoa aiheuttaviin tapahtumiin varaudutaan usein puutteellisesti. Tämä aiheuttaa tehottomuutta, koska ennaltaehkäisy on kustannustehokas tapa hallita monia tautiriskejä. Tuottajien vastuun lisäämisen tarkoituksena ei ole pelkästään vahinkojen rahoittaminen, vaan sillä tuetaan myös ennaltaehkäisevää riskinhallintaa. Tässä tutkimuksessa tarkastellaan keinoja, joilla ulkoisvaikutukset huomioon ottava ja ennaltaehkäisyyn kannustava rahoitusjärjestelmä voitaisiin toteuttaa. Tarkastelemme riskiperusteista rahoitusta, jossa rahoitusjärjestelmän ominaisuudet määritetään siten, että ne palkitsevat bioturvallisuutta lisäävistä ja rankaisevat sitä heikentävistä toimenpiteistä tai ominaisuuksista. Tarkasteluun liittyy kaksi teemaa: 1) kenen pitäisi osallistua rahoitukseen ja tulisiko osallistumisen olla vapaaehtoista vai pakollista; ja 2) miten maksut voidaan asettaa riskiperusteisesti.

Järjestelmän rahoitukseen tulisi osallistua niiden, jotka aiheuttavat ulkoisvaikutuksia muille. Esimerkiksi kysymys harrastetilojen osallistumisesta liittyy siihen, aiheuttavatko ne riskin muille tiloille. Ammattimaisten tuottajien osallistuminen tulisi olla mahdollisimman laajapohjaista. Laaja osallistuminen voidaan toteuttaa joko lainsäädännöllisesti tai riittävän voimakkailla taloudellisilla kannustimilla.

Maksut voivat perustua joko alueelliseen tai tilakohtaiseen riskiin. Jotta voidaan välttää vain suuren riskin tilojen osallistuminen järjestelmään (ns. haitallinen valikoituminen), tulee kullekin tilalle tai tilatyypille asettaa sen riskitasoa vastaava ja muut vaihtoehdot kyseiselle tilatyypille kannattamattomaksi tekevä maksu. Järjestelmä tulee suunnitella niin, että esimerkiksi suuren riskin tilat valitsevat juuri heille suunnitellun vaihtoehdon. Moraalikatoa eli vakuutetun toimintatapojen muuttamista riskialttiimmiksi vakuutuksen ottamisen jälkeen voidaan ehkäistä riskiin perustuvilla maksuilla. Palkkioita (bonuksia) voidaan myöntää esimerkiksi taudin esiintymättömyydestä tai varmennetuista ennaltaehkäisyyn tähtäävistä toimista. Korotettuja maksuja ja pienennettyjä korvauksia sen sijaan voidaan langettaa esimerkiksi myöhäisestä taudin ilmoittamisesta. Myös omavastuuosuus ehkäisee moraalikatoa.

\section{Asiasanat:}

Bioturvallisuus, eläintaudit, vakuutus, rahasto, riski 


\section{Introduction}

Animal diseases are costly to the society. The costs manifest in many ways, including the costs of prevention and control, direct and indirect production losses to various parties, the impacts of market reactions, and welfare losses due to health, environmental and cultural impacts of disease. Costs can incur in disease-free times, upon an outbreak, and after the outbreak. The costs ensue to different parties, including the government, producers and consumers, and present a risk to those involved. Economically efficient use of resources requires that society takes into account the potential for externalities when designing and implementing risk management policy. Externalities (or external effects) refer to the problem where an action taken by one economic agent (e.g. producer) impacts other agents but that the agent taking the action does not take these impacts into account. For instance, a producer may not fully take into account that a pathogen may spread to the neighbouring farms when adjusting his/her farm's biosecurity. Similarly, an importer of animals may not take into account that the importing of animals exposes the whole sector to the risk of an infection.

One of the main objectives in managing the risk of infectious animal diseases is often to prevent a pathogen from entering an uninfected country or premise, or from leaving an infected premise. Prevention is in many occasions the most economical management option for biological hazards such as invasive species and exotic diseases. However, this is often not reflected in social resource distribution (Finnoff et al. 2007) and the current schemes for financing animal disease outbreaks hardly promote preventive actions.

Hence, when the government is designing a risk management policy, it is of primary importance to take into account the behaviour of individual producers in order to prevent harmful externalities from occurring, and to promote prevention as a management strategy. We suggest that a cost sharing scheme such as insurance or a mutual fund can promote these goals, provided that the scheme is designed to do so. By cost sharing we mean that the costs of animal disease risk are paid partly by government and partly by individual producers through specifically designed schemes. When designing the cost sharing scheme, it needs to be taken into account that producers respond to changes in the risk of disease as well as other economic incentives associated with the risk. It has, for instance, been established that the amount of compensation paid for the producers affects the number of disease notifications by the producers (Kuchler and Hamm 2000, Wineland et al. 1998). We propose that if cost sharing schemes are based on risk, they can be used to motivate producers into societally optimal biosecurity and hence to account for the externalities. Our aim in this paper is to discuss how the scheme could be designed in order to fulfil this task. More specifically, we discuss how economic problems such as external effects, moral hazard and adverse selection can be taken into account in funding animal disease epidemics. We point out both the benefits and the challenges of using risk as the basis for the funding scheme. As interest for cost sharing in animal disease context is increasing, it is important to take these issues into account in order to reap the full benefits from the scheme. Furthermore, we suggest that in order to avoid some challenges attached to risk-based funding, it might be profitable to apply contracts that avoid deterministic risk classification by the authorities.

\section{Cost sharing as a mean to fund provision of a public good}

The current animal disease financing system has several weaknesses (Civic Consulting 2006). It has been argued to be slow and bureaucratic, and seen as a risk to the community or state budget, as the maximum compensations have not been set. Unpredictability of compensation expenditures is also seen as a caveat, since a portion of compensation is subject to government discretion and not predetermined agreements. Further, consequential costs are seldom covered, which may result in producers having incentives for instance to transport seemingly healthy animals in order to avoid the costs of specific preventive measures (e.g. Niemi et al. 2004). An important caveat for economic efficiency of risk management policy is that the current scheme is not designed to transfer risk or to provide the producers with incentives to maintain biosecurity and notify diseases timely. The system does not take into account that a number of factors can affect the risk associated with a farm: for instance, farm size, production line, production methods and the location of the farm. Moreover, the costs of pre-emptive culling or other preventive practices are not compensated in most EU countries, despite prevention usually being the most cost-efficient method of disease control. Jin and McCarl (2006) argue that preventative measures taken by producers are insufficient because the investments are costly, free-riding lowers the incentives for investments, and the current systems offer no incentives for disease prevention.

Furthermore, since there are differences between the farms, a system that treats all the farms similarly is unlikely to be cost-efficient. Previous literature suggests that the risk management policy chosen by a farm is dependent on its' risk level as well as the risk posed by other farms. The problem with the lack of riskbased approach is that it can bias resource allocation. Jansson et al. (2006), for instance, present a simple example regarding the finance of animal disease losses. Their analysis illustrates that if regions are not held liable for disease losses in proportion to their risk level, the low-risk areas end up subsidising the high-risk 
areas, because the high-risk areas can benefit from the disease losses being covered by public funds (see also Jin and McCarl 2006). This implies that production can agglomerate into high-disease-risk regions. The problem applies within the European Union as well as within individual member states.

The objective of economically optimal resource allocation is not the maximum amount of security or maximal disease prevention, but rather an optimal amount of security, which is determined by the probabilities and monetary and non-monetary costs and benefits associated with the avoidance of disease. One of the major barriers for the society to reach an economically optimal level of biosecurity is that individual economic agents consider the costs or benefits of their actions from their own perspective. Hence, they do not consider all the costs and benefits that are relevant to the society. Freedom from disease is a public good that all animal producers enjoy. Public goods cannot be divided into separate soldable units. Moreover, once produced, no one can be prevented from benefiting from the good. While protecting his/her own farm against a disease, producer ends up protecting also all nearby and connected farms. Similarly, when taking a personal risk by not protecting against a disease, the producer risks all other agents and typically does not take this effect into account in his/her decision-making. As the producer does not account for these external impacts, the included costs and benefits do not represent the true costs and benefits, and disease protection is produced in insufficient quantities. Further economic incentives to take these effects into account are therefore required.

Most people dislike risk. Traditional dimensions of risk include the probability of a harmful event and the magnitude of impacts of this event. Risks can be reduced through a variety of methods, such as risk avoidance, probability reduction, impact reduction or risk transfer. One possibility for transferring risk as well as for reducing the event probabilities and impacts is cost sharing. Cost sharing can be considered to be an agreement, where the parties to the contract include the agent and the principal. One of the fundamental ideas in cost sharing is that the agent (e.g. producer) pays a predetermined premium to a principal (e.g. state, insurance company or farmer co-operative) who agrees to cover predetermined cost items if a disease outbreak occurs. Functioning of such a system can be analysed using the principal-agent model, where both parties maximise their own utility but do not know with certainty how the other party will behave and when the risky event will occur. For instance, the principal does not know with certainty the level of risk associated with individual agents (farms). It can be shown that insurance or equivalent cost sharing system is an efficient way to reduce production risks and to transfer them to a party that is better capable of carrying the risk (e.g. insurance company). If a fairly priced insurance is available, it is economically rational for a risk averse producer to have such insurance.

Besides reducing cost fluctuations over time and between farms, the principal can use the premium to provide producers with economic incentives to maintain appropriate biosecurity, detect the disease timely, notify the authorities and to comply with their instructions. In other words, cost sharing not only promotes risk transfer but can also be used to reduce the probabilities and impacts of harmful events. The underlying motivation is that if the society covers the damages unconditionally, it changes the incentive structure dramatically: the benefits from risk-taking accrue to private agents who take risky actions whereas the costs are covered by the society as a whole. Such a policy can support risk-prone production. By sharing the costs of risks this problem can be reduced. When the producers are involved in funding the risk, they can be imposed costs such that they internalise the true cost of risk in production decisions. This is the basic idea of the polluter pays principle. Hence, stakeholder contribution to costs should be based on the risk they pose to society.

\section{Risk definition in cost sharing}

If the starting point is that the cost sharing scheme and its contributions are related to risk that different actions or agents produce, then the risk must be clearly defined. Measurements of risk may be based on different indicators which reflect the actual risk. The risk indicators can be related to two primary factors: regional risk or farm-specific risk. As for regional risk measures, farm and animal density are known to affect the local spread of diseases and the costs of risk management measures. Similarly, wild animals and climatic conditions are known to promote the spread of certain diseases, such as bovine tuberculosis and bluetongue, and can be linked to geographic regions. One benefit from such a scheme is that it is relatively easy to define the areas, although the border areas are a challenge. For instance the cost sharing scheme in Germany accounts for the regional differences in risk (Civic Consulting 2006). However, indicators based on the location of a farm are in practice exogenous after the decision to start production at a site has been made.

Another way to target the measures is according to the farm-specific characteristics, which are partly or fully endogenous to the producer. The factors can affect either the probability of disease spreading into the farm or the probability of the disease spreading from the farm. However, indicators solely based on farm size or type are not particularly good indicators for the risk caused by the farm (Lyytikäinen and Kallio 2008). The reason is that even if the presence of risk factors for disease spread is correlated with farm size and type, 
it is usually not farm size or type as such that is the cause for the risk of disease spread. Better indicators for the risk related to a certain farm can include the number and type of animals (species, age, production line), the number of animal contacts, or the biosecurity measures in place at the farm.

From an incentive perspective it is valuable that the producer can genuinely affect the level of risk and its indicator. Regarding area-specific risks this may be impossible. It is, however, possible to combine the two risk factors by having for instance a region-specific base premium which is then adjusted by the farmspecific risk factors. In practice, risk-classification of the farms is challenging. Meuwissen et al. (2002) analysed the possibilities for differentiating the premiums based on the farm characteristics (farm type, location, animal transport frequency, etc.) in the Netherlands. They found that such differentiation was possible only for farms that import animals into the country. They noted that there may be large differences between the farms, but these may not be systematic or strong enough, or that the criteria are not likely to hold in a judicial context. Considering these aspects, it may be beneficial to avoid problems and administrative burden caused by deterministic classification of farms by offering the producers different types of contracts from which they choose the type most appropriate for them. Such an approach requires that economic incentives are designed for the producer to take the alternative which society prefers him/her to choose. Recent studies suggest that there is now potential in classifying the farms according to their ability to spread diseases (Lyytikäinen and Kallio 2008). Such criteria could be useful for determining the incentive structure in cost sharing schemes.

\section{Foundation for Risk-Based Cost Sharing}

Finding ways to promote prevention and account for the risks can in practice be achieved by considering two principal factors: participants of the scheme and the premiums imposed on those participants. There are some special properties we propose to be required from the scheme: 1) all relevant stakeholder groups should be involved in the scheme; 2) the participants need to have an incentive to participate in the scheme; 3) the participant should find it optimal to accept the contract designed for his/her level of risk; and 4) the participant behaviour should not change to accepting greater risks (but rather vice versa) after participating in the scheme. The properties relate to well-known market failures: externalities and asymmetric information, which refers to the principal not knowing exactly the risk type and actions of individual agent. We discuss next how these issues can be solved through the choice of participants and premiums.

\section{Properties 1 and 2: The participants}

There are two main questions related to participants of a funding scheme: who should participate and should participation be voluntary or compulsory. Government participation in funding animal disease losses is justified by the existence of market failures or issues related to equality and income distribution, and by major public importance of certain diseases (e.g. zoonoses). Producer participation on the other hand can be used to promote prevention and the polluter pays principle. Other potential participants include for instance the recreational sector that has animal-based production (e.g. zoos and animal yards), hobbyists such as hunters and home-producers, and stakeholders such as food processing industry and retailing. If the amount of individual stakeholders or stakeholder groups is large, the transaction costs of the scheme can be elevated. When determining the participation of a stakeholder group it is therefore essential to consider whether the risk presented by that group is large enough to require their attention. In the context of cost sharing this may be the case especially if their contact with other animal population is minimal. Such agents could include for instance pet pig owners or small backyard poultry houses, who can also be difficult to identify individually. However, it is important to ensure that also stakeholders who are left out of the cost sharing scheme have proper incentives and knowledge for maintaining on-site biosecurity. This can be promoted through, for instance, the provision of information and legislative sanctions.

The question about compulsory versus voluntary participation for those stakeholders who are eligible to participate in the scheme is related to the external effects. If the disease causes important external effects and has a high social relevance, the disease should be covered by a compulsory cost sharing scheme. For diseases with some but not much externalities the scheme may be compulsory or voluntary. For diseases with no external impacts, the scheme should be fully voluntary as control of such diseases is a private good and there is no reason for society's involvement (Civic Consulting 2006). Also from the incentive perspective it might be necessary that participation is compulsory for at least some major diseases. If participation is not compulsory, mostly the high risk farms would be having the insurance, which would increase the compensation payments and hence the costs and price of insurance. Eventually, participation rate would be low as the price of insurance would be too high for the low-risk farms. This problem arises in cases where the principal is unable to differentiate between the low-risk and high-risk farms, a phenomenon known as adverse selection. Besides adverse selection, cognitive dissonance can reduce participation rate. It refers to reduced demand for protection against events with a small probability of occurrence because the agents do 
not recognise sufficiently the need to cover such low-probability risks (e.g. Akerlof and Dickens 1982, Kuhnreuther and Pauly 2004, Skees and Barnett 1999).

Both of these factors on their own, and especially together, lead to demand being too low from a social perspective. Hence compulsory nature of the scheme for diseases with significant externalities seems warranted. Compulsory participation has also drawbacks, as dictated solutions are not to everyone's liking. Therefore it is essential that all incentives have been designed such that all producers have an incentive not to break the rules of the scheme. Further, also the current financing system involves compulsory participation - through payment of taxes.

\section{Properties 2 and 3: Magnitude of the premium}

In order to ensure the participation of producers and to avoid the problem of adverse selection, the scheme needs to provide no less value for the agent than leaving out of the scheme (individual rationality constraint). Furthermore, the option that best suits the agent's profile needs to be at least as beneficial to him/her as any other option offered by the scheme (incentive compatibility constraint). These constraints are essential to any scheme with voluntary participation. The individual rationality constraint deals with the incentives of the agents to participate in the scheme. An agent chooses to participate in a (voluntary) scheme only if s/he receives net benefits from it. In other words, the insurance needs to provide a better cover for the disease loss than any other way of preparing for the risk (e.g. Bolton and Dewatripont 2005). The incentive compatibility constraint deals with the efficiency of the instrument when facing imperfect or asymmetric information. The problem regarding efficiency can be solved using the revelation principle. The basis of the principle is that it is sufficient that each type of agent (e.g. agents with different exposure to disease risk) is offered a menu of contracts where one specific contract is optimal for that agent, and the optimal contract enforces disease risk management practices desired by the principal. However, it has to be made sure that a particular type of agent has no incentive to choose a contract designed for another type of agent (Bolton and Dewatripont 2005). In practice the condition means that when differentiating the premiums based on the disease risk, the high risk farms should have no incentives to choose contracts designed for low risk farms, and vice versa.

The agents compare the premium set by the principal to their expected disease costs, adjusted by their degree of risk aversion. It can be shown in a simple setting that when there is asymmetric information, lowrisk and high-risk farms can both be induced to participate voluntarily only if 1) both are treated and priced as low-risk farms; or 2) both are treated and priced according to their individual level of risk. The first option is not sustainable, as the principal would be making a continuous loss. If any other flat rate premium (either at the level of the high-risk farm or the average of the farms) is set, the low risk farm would have no incentive to participate in the scheme. Hence the farms should face a funding scheme that offers an alternative which is priced according to their individual level of risk.

\section{Property 4: Rewards and sanctions}

Rewards (bonus) and sanctions are mechanisms that can be used to provide incentives for the producers and control for moral hazard. Moral hazard here refers to the problem that an agent has participated in a funding scheme, and her/his behaviour is altered such that s/he now takes greater risks. A few types of bonuses and sanctions are discussed below. The actual factors that they are connected to can differ in the different schemes or regions, because they should be connected to risk factors, which may differ between regions or countries. For instance, if in some region animal transport is the most important risk factor, it is sensible to relate some bonus or sanction to this factor.

Bonus for disease-freedom: A long period without failures is good news for the functioning of the scheme. Similarly, a history of disease freedom may indicate that the producers are investing in biosecurity or that the risk is otherwise low, and can be rewarded through a bonus for disease freedom, as is the case in for instance traffic insurance. Bonus based on historical disease incidence data is easy to verify, but may encounter identification problems in the short run and when probability of disease occurrence is small. One problem that has been noted (Civic Consulting 2006) regarding this bonus is the possible conflict with early notification of disease. If the producer faces the threat of losing the bonus, disease suspicions may not be notified as rapidly as otherwise would be the case, instead hoping that the disease simply disappears from the farm. This results in larger spread potential, increasing the aggregate costs of the ensuing outbreak. It has been suggested, and in some cases also applied, that the bonus could be formulated such that notifications before the restriction zone is established would not lead to loss of the bonus, ensuring the incentive for early notification (Civic Consulting 2006).

Bonus for prevention: Bonus related to preventative measures could be used as one mechanism to provide incentives for disease prevention (Gramig et al. 2006). Jin and McCarl (2006) suggest paying additional compensation for farms using certified and verified prevention measures. One problem with prevention bonus is that verifying and observing the actions is difficult. Hence the prevention bonus should 
be related to actions that are easily verifiable, for instance all in all out -practice or vertical integration that reduces the number of animal contacts.

Sanctions for late notification: It is important that actions for disease notification and subsequent eradication are taken as rapidly as possible. It has been noted that notifications are increased by higher levels of compensation (Kuchler and Hamm 2000, Wineland et al. 1998, Valeeva and Backus 2007, Jin and McCarl 2006). This requires that the producers can detect the disease and have incentives to notify the authorities of their suspicions. One mechanism to speed up notification is to use a specified sanction to punish for late notification. For instance, the magnitude of the compensation payment can be reduced depending on how quickly the producer has responded to the disease symptoms. The actual triggers might include dead or clearly sick animals or high herd disease prevalence at the time the veterinarian arrives to the premises. Caution is warranted, however. First, the possible conflicting interest with disease freedom bonus and its disincentive for early notification needs to be considered. Second, the disease characteristics (including infectivity, gestation period and symptom observability) need to be accounted for, and third, there may be a time lag from the notification to vet arrival. For instance in Belgium and the Netherlands there is a scheme where high disease prevalence or mortality before notification lowers the compensation. In Switzerland the losses need to be reported within 24 hours to ensure full compensation (Civic Consulting 2006). Kuchler and Hamm (2000) and Wineland et al. (1998) report that the producer motivation to find sheep infected with scrapies was increased as the level of compensation increased. Valeeva and Backus (2007) show how from a producer perspective it is more economical to report classical swine fever symptoms early and fast when the producer has to carry a larger proportion of the costs of the dead animals, achieved through lower compensation or increased fines. In summary, the earlier the disease is notified the higher should the producer payoff be.

Deductible: A deductible which is subtracted from the compensation can be used to control moral hazard. In fact, Gramig et al. (2008) note that a deductible (or other similar mechanism) is essential in order to avoid the problem of moral hazard and to provide the producer sufficient incentives to maintain a good level of biosecurity. However, as Shaik et al. (2006) note, a large deductible can reduce moral hazard, but at the same time it weakens the incentives for early notification of the diseases.

\section{Conclusions}

We have discussed risk as the basis for a cost sharing scheme. When stakeholder participation in financing the risk is risk-based, it is possible to control for the externalities present, as well as control for the problems of adverse selection and moral hazard. Through the contract mechanism it is possible to motivate the producers to act more rather than less cautiously after participating in the scheme - hence promoting prevention of diseases. We have suggested that adverse selection can be controlled through premium differentiation, as well as through provision of incentives or requirements for participation. Moral hazard can be avoided through a deductible and appropriate sanctions, and prevention can be promoted through timing of the premium as well as by imposing lower premiums for low-risk participants. In addition, premium bonuses for prevention can be used. Instead of a prevention bonus one might also consider providing the producers with options, from which they can choose the one most suitable for them. This could be for instance 1) a larger annual premium, no specific prevention requirements; 2) a smaller annual premium, requires carrying out specified preventative actions.

The advantages of the risk-based approach can be summarised as follows: 1) polluter pays; 2) small risk areas/farms do not subsidise high risk areas/farms; 3) risk classification helps designing and targeting also other risk management; 4) externalities are better accounted for; 5) prevention is promoted; and 6) the scheme is transparent. The challenges in risk-based approach are: 1) transaction and administrative costs may be large; 2) the resulting distribution of costs and benefits may be difficult for high risk areas; and 3) it may be challenging to find commonly accepted measures for risk. It is vital that the scheme is designed so that all producers have sufficient economic incentives to comply with the rules desired by society. Using the contract mechanism, it is potentially possible to reduce the administrative costs as well as to avoid determined classification of the farms.

Some of the issues discussed in this paper are independent of each other. For instance, a bonus can be used as a mechanism regardless of whether the premium itself is risk-based or not. However, as we have noted there are problems to solve, and not including all available mechanisms in the scheme may mean that some potentially problematic issues are not resolved, hence endangering the entire scheme. We have addressed the issue from the point of view of efficiency. An analysis could take also other objectives and find that some properties may be desirable from the point of cost-efficiency, but may be undesirable from another viewpoint (e.g. equity). For instance, Jansson et al. (2006) show how the costs of insurance can vary widely if the premiums are differentiated based on risk. According to their results, the regional impacts on income and income distribution within the European Union from a risk-based insurance could be remarkable. 
Risk-prone farms and areas would lose in a move to a risk-based financing scheme. On the other hand, this is more or less the objective in the risk-based approach, as it is those risk-prone farms and areas that are currently imposing external costs on others.

\section{References}

Akerlof, G.A. \& Dickens, W.T. 1982. The Economic Consequences of Cognitive Dissonance. The American Economic Review 72 (3): 307-319.

Bolton, P. \& Dewatripont, M. 2005. Contract Theory. Cambridge: MIT press.

Civic Consulting. 2006. Evaluation of the Community Animal Health Policy (CAHP) 1995-2004 and alternatives for the future. Final Report. Part II: Pre-feasibility study on options for harmonised cost-sharing schemes for epidemic livestock diseases. European Commission. DG SANCO. Brussels.

Finnoff, D., Shogren, J.F., Leung, B. \& Lodge, D. 2007. Take a risk: preferring prevention over control of biological invaders. Ecological Economics 62: 216-222.

Gramig, B.M. \& Wolf, C.A. 2007. Estimating within-herd preventive spillovers in livestock disease management. American Journal of Agricultural Economics 89: 1219-1225.

Gramig, B.M., Barnett, B.J., Skees, J.R. \& Black, J.R. 2006. Incentive compatibility in risk management of contagious animal diseases. pp. 39-52. Teoksessa: Hoag, D.L., Thilmany, D.D. and Koontz S.R. (eds.). 2005. The economics of livestock insurance: concepts, issues and international case studies. Cambridge: CABI Publishing.

Jansson, T., Norell, B. \& Rabinowicz, E. 2006. Modelling the impact of livestock disease insurance in the European Union. s. 233-251. Teoksessa: Hoag, DL, Thilmany, DD \& Koontz SR (ed.). 2005. The economics of livestock insurance: concepts, issues and international case studies. Cambridge: CABI Publishing.

Jin, Y. \& McCarl, B.A. 2006. Animal Disease Related Pre-event Investment and Post-event Compensation: A Multiagent Problem. Selected Paper prepared for presentation at the American Agricultural Economics Association Annual Meetings, Long Beach, California, July 23-26, 2006.

Kuchler, F. \& Hamm, S. 2000. Animal disease incidence and indemnity eradication programs. Agricultural Economics 22: 299-308.

Kuhnreuther, H. \& Pauly, M. 2004. Neglecting disaster: why don't people insure against large losses? Journal of Risk and Uncertainty 28 (1): 5-21.

Lyytikäinen, T. \& Kallio, E. 2008. Risk-classification of Finnish pig farms by simulated FMD spread. p. 285-300. In: Proc. Society of Veterinary Epidemiology and Preventive Medicine annual meeting, 25-28th March 2008, Liverpool, UK.

Meuwissen, M., Mourits, M., Mangen, M-J., Léon, C., Tomassen, F. \& Huirne, R. 2002. Differentatie heffingen diergezondheidsfonds varkenhouderij. Institute for Risk Management in Agriculture (IRMA) and Farm management group, Wageningen University and Research Centre. Working Paper. 12 p.

Niemi, J.K., Pietola, K. \& Sevón-Aimonen, M.-L. 2004. Hog producer income losses under contagious animal disease restrictions. Agra Agriculturae Scandinavica section C - Food economics 1: 185-194.

Shaik, S., Barnett, B.J., Coble, K.H., Miller, J.C. \& Hanson, T. 2006 Insurability Conditions and Livestock Disease Insurance. pp. 53-67. Teoksessa: Hoag, D.L., Thilmany, D.D. \& Koontz, S.R. (eds.). 2005. The economics of livestock insurance: concepts, issues and international case studies. Cambridge: CABI Publishing.

Skees, J.R. \& Barnett, B.J. 1999. Conceptual and practical considerations for sharing catastrophic/systemic risks. Review of Agricultural Economics 21 (2): 424-441.

Valeeva, N. \& Backus, G. 2007. Incentive schemes under ex post moral hazard to control outbreaks of Classical Swine Fever in the Netherlands. Selected paper prepared for presentation at the American Agricultural Economics Association Annual Meeting, Portland, OR, July 29 - August 1, 2007.

Wineland, N.L., Detwiler, L. \& Salman, M. 1998. Epidemiologic analysis of reported scrapie in sheep in the United States. Journal of American Veterinary Medicine Association 212: 713-718. 